VOX PATRUM 29 (2009) t. 53-54

Ks. Andrzej UCIECHA

(Katowice, UŚ)

\title{
RELIGIJNY PROGRAM WYCHOWANIA W UJECCIU JANA CHRYZOSTOMA
}

Pedagogiczne postulaty Jana Chryzostoma kształtowały się w konkretnym środowisku społeczno-religijnym syryjskiej Antiochii drugiej połowy IV wieku. Obywatele tego miasta, w tym również chrześcijanie, poszukiwali przyjemności, namiętnie pasjonowali się wyścigami konnymi i za swój obowiązek uważali udział $\mathrm{w}$ przedstawieniach teatralnych. Jak pisze J.N.D. Kelly, mieli oni opinię światowców, materialistów i cyników, którzy wiosną i latem udawali się do pobliskiego Dafne ${ }^{1}$. W badaniach tematu wychowania należy również uwzględnić silny wpływ ideałów życia monastycznego, któremu Złotousty z zapałem oddawał się począwszy od asketerionu Diodora, przez cztery lata umartwień monastycyzmu na wpół cenobitycznego na górze Silpios, aż po wyczerpującą ascezę pustelnika, która doprowadziła do załamania jego stanu zdrowia ${ }^{2}$. W życiu Chryzostoma ideały ascetyczne odgrywają tak istotną rolę, że nie wolno ich pominąć przy omawianiu jego nauczania pedagogicznego.

Badacze sygnalizowali już różne aspekty tematyki religijnego wychowania w ujęciu Jana Chryzostoma ${ }^{3}$, dlatego postaramy się najpierw wydobyć i przeanalizować te wątki, które zostały pominięte albo opracowane pobieżnie, na-

\footnotetext{
${ }^{1}$ Por. J.N.D. Kelly, Złote usta. Jan Chryzostom - asceta, kaznodzieja, biskup, thum. K. Krakowczyk, Bydgoszcz 2001, 15.

${ }^{2}$ Por. tamże, s. 35-46.

${ }^{3}$ Zagadnienie paideia u Jana Chryzostoma analizowali A. Bober, Rodzina Kościołem domowym wedlug św. Jana Chryzostoma, VoxP 5 (1985) z. 8-9, 193-200; M. Gärtner, Familienerziehung in der Alten Kirche, Köln 1985; A.H.M. Jones, St. John Chrysostom's parentage and education, HTR 46 (1953) 171-173; W. Kania, Pierwsza rodzinna katecheza domowa w ujęciu św. Jana Chryzostoma, VoxP 5 (1985) z. 8-9, 215-222; L. Meyer, Saint Jean Chrysostome maître de perfection chrétienne, Paris 1933; H. Wójtowicz, Zadania rodziny chrześcijańskiej w nauczaniu św. Jana Chryzostoma, VoxP 5 (1985) z. 8-9, 201-214; E. Stanula, Rodzina ksztaltująca system wartości w ujęciu św. Jana Chryzostoma, w: Wychowanie $w$ rodzinie od starożytności po wiek XX. Materiały z Konferencji (czerwiec 1993 r.), Bydgoszcz 1994, 81-94; A. Uciecha, Rodzina miejscem wychowania w traktacie pedagogicznym „O wychowaniu dzieci” św. Jana Chryzostoma, ŚSHT 19-20 (1986-1987) 65-92; M. Falanga, Il pensiero pedagogico di Giovanni Crisostomo, Bari 1981; T. Kołosowski, Wychowanie religijno-moralne dzieci $w$ rodzinie $w$ świetle traktatu „O wychowaniu” dzieci” ${ }^{\prime} w$. Jana Chryzostoma, „Seminare” 17 (2001) 405-420.
} 
stępnie przypomnimy metody religijnego wychowania, jakie Złotousty przedstawił w specjalnym traktacie $O$ wychowaniu dzieci $i^{4}$ i Homiliach na Ewangelie wedlug św.Mateusza ${ }^{5}$.

1. Religijne wychowanie w syryjskiej Antiochii IV wieku. Jako wnikliwy obserwator, utalentowany kaznodzieja i doświadczony duszpasterz Jan Chryzostom wypominał i zdecydowanie tępił błędy, jakie antiocheńscy rodzice popełniali w religijnym wychowywaniu swoich dzieci. W traktacie $O w y$ chowaniu dzieci ${ }^{6}$ oskarża chrześcijańskich ojców:

„Gdy dziecko się urodzi, cały wysiłek obraca ojciec nie na to, jak jego życio-

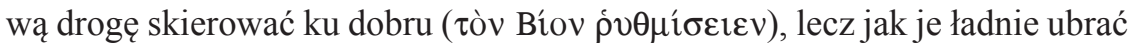
i przyoblec w złote ozdoby"7.

Pierwszorzędne zadanie kształtowania w dziecku umiłowania porządku i dobra spychane było na dalszy plan przez troskę o drugorzędne sprawy mate-

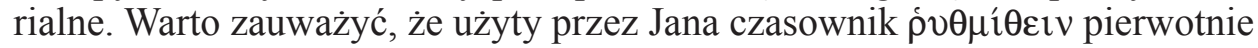
znaczy „,porządkować”, „,modelować swoje życie według określonego wzoru, ideału" . Złotousty krytykował ojca rodziny, ponieważ głównie na nim spoczywała odpowiedzialność za prawidłowe wychowanie potomstwa ${ }^{9}$. O trudnym obowiązku właściwego wychowania dzieci Chryzostom pisał już dekadę wcześniej w innym traktacie Przeciwko zwalczajacym życie monastyczne ${ }^{10}$. Oskarżał tam ojców, że ograniczają swoje powinności rodzicielskie do zapewnienia dzieciom jedynie materialnego dobrobytu, zdobycia pogańskiego wykształcenia i osiągnięcia kariery ${ }^{11}$. Podobne zarzuty, ale już pod adresem

${ }^{4}$ Por. Joannes Chrysostomus, De inani gloria et de educandis liberis, ed. A.M. Malingrey, SCh 188, Paris 1972, tłum. W. Kania, PSP 13, Warszawa 1974 lub BOK 19, Kraków 2002, 73-105 (tym ostatnim wydaniem się posługuję).

${ }^{5}$ Por. Joannes Chrysostomus, In Matthaeum homiliae 1-90, PG 57-58, thum. J. Krystyniacki, t 1-3, Lwów 1885; wydanie poprawione ŹMT 18 i 23, Kraków 2001 i 2003.

${ }^{6}$ Por. Kelly, Złote usta, s. 97: „Książka jest najstarszym zachowanym podręcznikiem zawierającym rozległy program moralnego i duchowego kształtowania młodych chrześcijan w domu dla dopełnienia wykształcenia, które otrzymują w szkole".

${ }^{7}$ De educandis liberis 16, SCh 188, 96, BOK 19, 79.

${ }^{8}$ Por. tamże, SCh 188,97 , nota 3.

${ }^{9}$ Por.K.Korus, Program wychowawczy Plutarchaz Cheronei, Kraków 1978, 57: „Wrzeczywistości grecko-rzymskiej zauważyć można znaczne osłabienie roli rodziców w wychowaniu i wykształceniu dzieci; najczęściej zrzucano obowiązek kierowania dziećmi na pedagoga, i to do okresu pajdycznego wyłącznie"; zob. A. Uciecha, Rola ojca w procesie wychowania domowego na podstawie traktatu św. Jana Chryzostoma „O wychowaniu dzieci”, w: Dziecko w rodzinie i spoleczeństwie. Starożytność Średniowiecze, red. J. Jundziłł - D. Żołądź-Strzelczyk, t. 1, Bydgoszcz 2002, 205-218.

${ }^{10}$ Por. Joannes Chrysostomus, Adversus oppugnatores vitae monasticae 3-4, PG 47, 351-354.

${ }^{11}$ Por. tamże 5-7, PG 47, 356-360. 
obojga rodziców, Chryzostom sformułował, zachęcając żony po śmierci męża do pozostania w stanie wdowieństwa ${ }^{12}$.

W podobnych słowach Jan czyni zarzuty braku należytej troski o chrześcijańskie wychowanie potomstwa, precyzując na czym powinno polegać owo kierowanie życia dziecka ku dobru (

„Już wam powiedziałem: zepsucia świata nie można dlatego usunąć, bo nikt nie zwraca uwagi na dzieci. Nikt nie mówi do nich o dziewictwie, czystości, pogardzie bogactw i sławy, przykazaniach Bożych, które nam podaje Pismo Święte. Jeśli dzieci od młodości wzrastać będą bez pouczenia, cóż z nich będzie? Jeśli od wczesnego dzieciństwa do starości wychowywani popadają w grzechy, ileż złego uczynią ci, których ucho od młodości przyzwyczaiło się do mów światowych! Ileż starania dokładają wszyscy, aby dzieci wykształcić w sztuce, nauce i wymowie, a nikt nie dba o wyćwiczenie duszy!"”3.

Fundamentem religijnego wychowania potomstwa pozostają ideały zawarte w Piśmie Świętym. Dla Jana, który monastyczną ascezę uważał za najwłaściwszą formę wyrazu i realizacji chrześcijańskiego życia, najcenniejszym skarbem przekazywanym dziecku w domu rodzinnym są dziewictwo, czystość i pogarda dóbr ziemskich. Możliwe, że sceptyczny ton i narzekanie Kaznodziei należy traktować z dystansem jako krasomówczy chwyt, niemniej jednak nie powinniśmy całkowicie negować jego wartości historycznej. Pasja, z jaką Chryzostom przemawia i upomina, wyraźnie świadczy o realnym zagrożeniu chrześcijańskiej edukacji dzieci i słabnącej odpowiedzialności wychowawczej ojców w antiocheńskim Kościele. Złotousty nie może nie mówić głośno o tym, co niszczy chrześcijańską rodzinę i zdecydowanie reaguje na rozmywanie się chrześcijańskich ideałów w pogańskiej obyczajowości.

Jan nie może milczeć i w jednej z Homilii na Ewangelię wedtug św. Mateusza znowu zwraca się przeciwko bezmyślności chrześcijańskich ojców:

„Istnieją ludzie - i nie jest to żart - gorsi od dzikich zwierząt żyjących na pustkowiu i wierzgających. Większa część młodzieży jest u nas taka, bo ulegając dzikim namiętnościom w ten sam sposób skaczą, wierzgają, chodzą bez uzdy i przykładają się do rzeczy niepotrzebnych. A winni są temu ojcowie, którzy zmuszają ujeżdżaczy, by z wielką starannością ujeżdżali ich konie, i nie pozwalają, by źrebię chodziło długo nie ujarzmione, lecz zaraz od początku każą mu zakładać wędzidło i wszystko inne, a nie zważają na to, że ich synowie długo chodzą bez uzdy, pozbawieni powściągliwości ściągają na siebie hańbę poprzez nierząd, grę w kości, przebywanie w bezbożnych teatrach. Tymczasem przed nierządem, należałoby takiego ożenić z roztropną i mądrą kobietą, która odwiedzie męża od najgorszych zajęć i będzie dla niego tym, czym wędzidło dla młodego konia [...]. Trzeba jeszcze zaczekać, powiesz,

\footnotetext{
${ }^{12}$ Por. In illud: ,, Vidua eligatur” 7 i 10, PG 51, 327 i 330.

${ }^{13}$ De educandis liberis 17-18, SCh 188, 100-102, BOK 19, 80.
} 
aby się wyróżnił, aby odznaczył się w sprawach publicznych. Natomiast o duszę nie troszczycie się wcale i nie zważacie na to, że jest sponiewierana. Dlatego wszystko pełne jest pomieszania, nieporządku i zamętu, ponieważ nie troszczą się o nią, nie starają się o to, co jest potrzebne, a przejawiają wielką zapobiegliwość względem rzeczy nie mających żadnej wartości. [...]. Wszak nasze dzieci mają dla nas mniejszą wartość niż bydło. Bardziej dbamy o konie i o osły niż o dzieci. Gdy ktoś ma muła, stara się znaleźć dla niego jak najlepszego woźnicę, (nie nazbyt surowego), nie złodzieja ani pijaka, lecz biegłego w swym zawodzie. Gdy zaś trzeba zatroszczyć się o nauczyciela dla duszy dziecka, bierzemy pierwszego lepszego, jaki się nawinie [...]. Ale co nam przyjdzie z tych skarg? Wprawdzie powstajemy przeciwko tej żądzy (pieniądza) w słowach, ona zaś ujarzmia nas w czynach. Mimo to nie przestaniemy ganić jej słowami. Jeśli bowiem coś przez to osiągniemy, wtedy zyskaliśmy my oraz wy; a jeśli będziecie trwać w waszych błędach, wtedy przynajmniej wypełniliśmy to, co do nas należało (por. Ez 3,16-21)"'14.

Dzieci wychowywane jedynie w materialnym dobrobycie i przysposabiane do kariery w życiu publicznym wyrastają na ludzi, które przypominają dzikie zwierzęta. Dosadność kaznodziejskiego porównania i ostrość oskarżeń mogły niejednego słuchacza dotknąć, ale przecież o to właśnie chodziło antiocheńskiemu Kaznodziei. Celem napomnień pozostaje chrześcijański pater familias, a przedmiotem krytyki jego bezmyślność.

Radykalizm pedagogicznej walki z chciwością i zbytkiem staje się zrozumiały w kontekście wyjaśnienia, w którym Złotousty stara się rozwiać wszelkie wątpliwości:

„Nie mówię: Wstrzymaj syna od małżeństwa, poślij go na pustynię i każ mu zostać mnichem. Prawda - chciałbym, aby wszyscy żyli jak mnisi”"15.

Utopijne ideały wychowania dzieci w klasztorach, jakie Jan formułował we wcześniejszym traktacie O obronie życia monastycznego, stały się jedynie nierealnym marzeniem w konfrontacji z rzeczywistością. Pasterskie dojrzewanie Antiocheńczyka po koniecznym wycofaniu się z życia w surowej anachorezie znajduje swój wyraz w reformie postulatów pedagogicznych.

2. Chryzostom jako pedagog-prorok. Wnikliwość obserwacji życia chrześcijańskich rodzin pozwalała Chryzostomowi dostrzegać takie zjawiska, na które nie zwracano uwagi. W słynnym fragmencie przeciwko próżności młodzieńców noszących ozdobne buty mówi tak:

„Wiem ja dobrze, że wielu [z was] się wydaje, iż zatrzymuję się długo nad drobiazgami. Mimo to nie zaprzestanę. Bo przyczyną wszelkiego zła jest wła-

\footnotetext{
${ }^{14}$ In Matthaeum hom. 59, 7, PG 58, 583-584, ŹMT 23, 224-226.

${ }^{15}$ De educandis liberis 19, SCh 188, 102-104, BOK 19, 80-81.
} 
śnie to, że uważamy te grzechy za małe i zaniedbujemy je. «Cóż może być mniejszym grzechem - ktoś powie - niż mieć ozdobny i błyszczący bucik, dopasowany do nogi; jeśli w ogóle jest czymś słusznym nazywanie tego grzechem»? Chcecie zatem, bym się na tym zatrzymał i przedstawił, jak wielka to nieprzyzwoitość? Nie będziecie się gniewać? Owszem, gniewajcie się, nie wiele na to zważam. Bo wy, którzy nawet nie uważacie tego za grzech, jesteście przyczyną tej głupoty i w ten sposób zmuszacie nas do występowania przeciwko tej rozrzutności"'16.

Złotousty krytykuje próżność młodzieńców, którzy noszą ozdobne buty i zamiast zdobywaniem wieczności, martwią się jedynie tym, co ziemskie i doczesne. Jan dowodzi, że źródłem złego wychowania dzieci jest lekceważenie znaczenia drobiazgów, z których składa się życie codzienne. Jak widać, walka z niebezpieczeństwem materializmu i pokusą chciwości jest stałym elementem Chryzostomowej paideia. W Homiliach na Ewangelię wedtug św.Mateusza Jan ujawnia motywy swojej postawy: nie może przestać napominać i wytykać błędów, mimo zarzutów (z pewnością rzeczywistych) o małostkowość w ocenie postępowania chrześcijańskich ojców. Prorocki obowiązek przemawiania wbrew woli słuchaczy i dla ich dobra leży u podstaw religijnego wychowania w ujęciu Jana Chryzostoma. Jako prorok gani on uleganie żądzy pieniądza ${ }^{17}$, przestrzega i zachęca ojców:

„Nie przestanę was upominać, prosić, zaklinać, abyście przede wszystkim wychowywali dobrze dzieci. Jeśli kochasz dziecko, okaż to czynem. Otrzymasz za to nagrodę"

Nieustanne upominanie chrześcijańskich ojców jest dla Złotoustego obowiązkiem duszpasterskim, który wynika z odpowiedzialności za grzeszników. Jako pasterz Kościoła Jan ma świadomość, że pełni funkcję proroka na wzór Ezechiela (por. Ez 3, 16-21). Stara się również przekonać ojców, że to oni właśnie jako głowy rodzin są prorokami dla swoich dzieci:

„Słyszę, że wielu mówi, iż słuchając kazania, gdy jesteśmy na nim obecni, zostajemy zbudowani, wyszedłszy zaś, stajemy się inni, tłumiąc w sobie ogień gorliwości. Cóż więc wypada czynić, by tak się nie działo? Zbadajmy, skąd się to bierze. Co wywołuje w nas taką zmianę? [Bierze się ona] z nieodpowiedniego trybu życia oraz z obcowania ze złymi ludźmi. Nie powinno się od razu po wyjściu z [naszego] zebrania rzucać się zajęciom niestosownym dla usłyszanej nauki, lecz przyszedłszy do domu zaraz wziąć księgę do ręki, przywołać żonę i dzieci do uczestnictwa w przypominaniu tego, coś słyszał, a dopiero potem przystąpić do zajęć domowych [...]. Jeżeli bowiem ktoś

\footnotetext{
${ }^{16}$ In Matthaeum hom. 49, 4, PG 58, 501C, ŹMT 23, 98.

${ }^{17}$ Tamże 59, 7, PG 58, 584, ŹMT 23, 226: „Mimo to nie przestaniemy ganić jej słowami”.

${ }^{18}$ De educandis liberis 19, SCh 188, , BOK 19, 80.
} 
otrzyma kilka denarów, chowa je do mieszka i pieczętuje; my zaś otrzymując nauki droższe od złota i drogich kamieni oraz skarbiec Ducha, nie składamy ich do izdebki naszej duszy (por. Mt 6,6), lecz po prostu pozwalamy, by ulatywały z naszego umysłu na chybił trafił. Któż ulituje się nad nami, jeżeli sami na siebie zastawiamy sidła i doprowadzamy się do takiego ubóstwa? By więc tak nie było, nadajmy sobie, naszym żonom i [naszym dzieciom] nienaruszalne prawo, byśmy jeden cały dzień w tygodniu przeznaczali na słuchanie i rozważenie tego, co usłyszeliśmy na zgromadzeniu. W ten sposób z większą łatwością i rozumieniem będziemy podchodzić do słuchania następnych nauk; my będziemy mieć mniej pracy, a wy większy pożytek"19.

Tak jak kapłan w kościele, tak ojciec w domu powinien dbać o przekaz i stosowanie słowa Bożego. Stosownie do miejsca przepowiadania obaj wypełniają funkcję proroka. Przepowiadanie domowe pater familias nie ogranicza się tylko do dzieci:

„By zaś nie powtórzyło się to samo - byście podziwiając wprawdzie rzeczy tu usłyszane, po powrocie, lekkomyślnie porzuciwszy tablice waszych dusz, nie pozwolili diabłu tego zmazać - niechaj każdy wróciwszy do domu przywoła żonę, niech jej to powie, weźmie ją jako pomocnicę i od dzisiejszego dnia wejdzie do tej pięknej palestry, używając jako oliwy zasobów Ducha"²0.

Napominanie jako forma przepowiadania prorockiego w budowaniu chrześcijańskiej rodziny skierowane powinno być również do żony. Zaznaczyć należy, że Jan wprost nie łączy tego obowiązku pater familias z wychowaniem dzieci, podkreślić jednak warto wspólne podłoże tych zadań ojca. Tym większa na nim ciąży odpowiedzialność, im więcej próżności widać w postępowaniu żony:

„Jeśli masz żonę lubiącą się stroić, przepadającą i uganiającą się za kosmetykami, skłonną do zbytków, gadatliwą i głupią, choć to może niewiarygodne, aby wszystkie te wady spotkały się w jednej kobiecie, ale wyobraźmy sobie taką kobietę [...]. niech jej mąż stara się usilnie na wszelki sposób ją poprawić. Jakże sprawi to, by się poprawiła? Tak, że nie wszystko nakaże jej od razu, ale najpierw odmieni rzeczy drobniejsze, do których nie jest zbyt przywiązana. Jeśli ją na początku przynaglasz, by poprawiła się we wszystkim, wtedy zmarnowałeś cały wysiłek. Nie pozbawiaj jej natychmiast złotych ozdób, lecz pozwól jej je mieć i nosić. Jest to, jak się wydaje, mniejsze zło niż bielidło i róż. Ich niech się najpierw pozbędzie, ale również nie pod wpływem strachu i groźby, lecz dzięki przekonywaniu i uprzejmości, gdy oskarżysz inne kobiety, wyrazisz własny osąd i zdanie w tej kwestii. Mów jej ciągle, że jej twarz, tak upiększona, nie tylko nie jest powabna, ale jest wręcz odrażająca.

\footnotetext{
${ }^{19}$ In Matthaeum hom. 5, 1, PG 57, 55, ŹMT 18, 68-69.

${ }^{20}$ Tamże 11, 8, PG 57, 202, ŹMT 18, 145.
} 
A uderzaj przede wszystkim w to, że cię to martwi. Oprócz twojej opinii, aby usunąć tę słabość, przytaczaj też sądy innych. Mów, że to szpeci nawet kobiety przystojne. Nie mów nic o piekle, ani o królestwie, bo nadaremnie będziesz to mówił. Przekonaj ją tylko, że sprawi ci większą przyjemność, gdy pokaże nienaruszone dzieło Boże, bo ta, która naciera, naciąga i bieli twarz nie uchodzi piękną nawet wśród pospólstwa. Staraj się leczyć tę chorobę najpierw ogólnymi dowodami i powszechnymi opiniami, a gdy ją zmiękczysz takimi mowami, wówczas dodawaj i tamto. Gdy powiesz raz, a nie przekonasz, wtedy nie ustawaj i powtarzaj te same słowa po raz drugi, trzeci i tak dalej; nie ze złością, a z łagodnością; to się odwracaj, to znów schlebiaj i bądź uprzejmy. Czy nie widzisz malarzy, którzy tyle zamazują i domalowują, gdy starają się, by twarz była piękna? Nie bądź gorszy od nich. Jeśli oni dokładają taki starań, malując postać cielesną, to jest o wiele bardziej słuszne, byśmy i my użyli całej sztuki, gdy kształtujemy duszę. Jeśli pięknie ukształtujesz oblicze duszy, nie zobaczysz wtedy szpetnej twarzy cielesnej: ani uczerwienionych warg, ust podobnych do zbroczonego krwią niedźwiedziego pyska ani brwi uczernionych jakby sadzą z jakiegoś garnka, ani policzków pobielanych jak ściany grobowców. Wszystko to jest sadzą, prochem i popiołem oraz oznaką największej zgnilizny. Oprócz tego przypominaj jej dawne niewiasty: Sarę i Rebekę, ładne i brzydkie, i pokazuj, że wszystkie były jednakowo skromne. Bo Lea, żona patriarchy, choć nie była ładna, nie czuła się zmuszona wymyślić coś podobnego, lecz mimo że była brzydka i że mąż niezbyt ją kochał, nawet nie pomyślała o niczym podobnym, nie niszczyła sobie twarzy, lecz pozostała zachowując niezmienione jej rysy, a czyniła tak, chociaż wychowała się wśród pogan. A ty jesteś kobietą wierzącą, twoją głową jest Chrystus (por. Ef 1, 10. 22; 1Kor 11, 3), i wprowadzasz nam szatańskie sztuczki? Czy nie przypominasz sobie wody, która spływała po twym obliczu, ofiary, która ozdobiła twe wargi ani krwi, która zabarwiła twój język? Jeśli będziesz pamiętać o tym wszystkim, to choćbyś była nie wiem jak żądna upiększeń, nie odważysz się nałożyć na siebie tego prochu i popiołu ani nie zniosłabyś tego. Wiedz, że zaślubiłaś Chrystusa: porzuć to, co nie przystoi" ${ }^{21}$.

Złotousty proponuje cały wachlarz argumentów i sposobów perswazji, które powinien wykorzystać ojciec rodziny, aby przekonać żonę do skromności i umiaru w ubiorze. Głowa chrześcijańskiej rodziny kieruje więc również wychowaniem żony. Kaznodzieja delikatnie zaznacza, że chodzi o chrześcijankę. Słowne napominanie nie może ustawać. Mąż jak artysta- malarz tworzy piękny obraz swojej żony, i podobnie jak z dziećmi, troszczyć się również musi o wygląd jej duszy.

${ }^{21}$ Tamże 30, 5, PG 57, 568-569, ŹMT 18, 361-362. 
3. Wychowanie atlety dla Chrystusa. Wdrażanie ideałów porządku i dobra $(\rho v \theta \mu i \zeta \xi \varepsilon v) \mathrm{w}$ dziecku i obrona przed materializmem posiada w nauczaniu Jana Chryzostoma wyraźnie religijne cele:

„Wtedy będziemy podobać się Bogu, gdy wychowamy bojowników Bożych

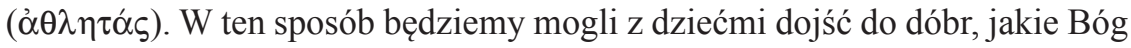
obiecał tym, którzy Go kochająa"22.

Tłumacz polski używa w powyższym przekładzie terminu ,żołnierz” lub „,bojownik" zamiast ,atleta”, tym samym zmienia nieco sens tekstu. W perspektywie doczesności trudy wychowania prowadzą do wykształcenia cech atlety Bożego, toczącego zwycięską walkę ze złem. Tym samym dziecko odkrywa i kształtuje w sobie wiarę w siłę dobra oraz wynikającą z niej umiejętność konstruktywnego rozwiązywania problemów. Ostatecznym jednak celem tych zmagań jest osiągnięcie zbawienia, czyli dobra wiecznego. W perspektywie wieczności więc dobra doczesne tracą na wartości a funkcja kierownika wychowania podporządkowana zostaje autorytetowi samego Boga, jako najwyższej i ostatecznej instancji pedagogicznej. Wobec tego autorytetu kierujący wychowaniem ojciec staje się wychowankiem:

„Udzielając chłopcu tych nauk, ojciec sam się wychowuje i postępuje w dobru ( $\rho v \theta \mu i ́ \zeta \omega v)$; w każdym dniu staje się lepszy, jeśli nie z miłości do cnoty, to z miłości do dziecka, bo go nie chce przez zły przykład zgorszyć" ${ }^{23}$.

Miłość do syna i świadomość wpływu na jego zachowanie wyzwala w ojcu obowiązek i potrzebę dobrego postępowania. Ponad zwykłą troską, aby nie zgorszyć, stoi wyższe pragnienie dobra (miłość do cnoty).

„Mając wiele grzechów na sumieniu, przez jedno możesz je zmazać: wychowaj żołnierza dla Chrystusa!"’24.

Trud religijnego wychowywania atlety dla Chrystusa zostaje dowartościowany, a jego skuteczność zbawcza porównana z modlitwą, postem i jałmużną.

„Dziecko jest pełne wstydu i szacunku, boi się wszystkiego, nawet twego widoku i głosu. Wykorzystaj swą powagę dla dobrego. Ty najpierw będziesz miał pociechę, mając dobrego syna, a także radość będzie dla Boga. Pracujesz dla siebie" ${ }^{25}$.

Odwołanie się więc do argumentacji religijnej w zasadniczy sposób wpływa na charakter relacji wychowujący - wychowywany: obaj podlegają autorytetowi samego Boga; ponadto, jeden dla drugiego stwarza, choć w różnym

\footnotetext{
${ }^{22}$ De educandis liberis 90, SCh 188, 196, BOK 19, 103.

${ }^{23}$ Tamże 70, SCh 188, 170, BOK 19, 97.

${ }^{24}$ Tamże 19, SCh 188, 102, BOK 19, 80.

${ }^{25}$ Tamże 20, SCh 188, 104, BOK 19, 81.
} 
zakresie odpowiedzialności, niezbędne warunki do rozwoju osobowości ${ }^{26}$, a co najważniejsze, pobudza myśl o zbawieniu. W ujęciu Jana argumentacja religijna wydaje się najbardziej logiczna.

Wychowanie Chrystusowego atlety (por. 1Kor 9, 24-26; 2Tm 2, 5) wymaga zastosowania konkretnych środków pedagogicznych; Złotousty proponuje następujące ćwiczenia:

a) opanowywanie gniewu i umiejętność milczenia ${ }^{27}$,

b) hartowanie ciała przez noszenie skromnego ubrania i rezygnację z miękkiego posłania ${ }^{28}$,

c) lektura historii biblijnych w miejsce pogańskiej mitologii ${ }^{29}$,

${ }^{26}$ Por. Uciecha, Rola ojca, s. 207-208.

${ }^{27}$ Por. De educandis liberis 68, SCh 188, 166, BOK 19, 96: „Dobrze jest, gdy chłopca wielu pobudza do gniewu, bo wtedy wyćwiczy się on w opanowaniu swych poruszeń. Jak atleci przed otwarciem zawodów ćwiczą siłę i w palestrze walczą dla próby ze swymi przyjaciółmi, aby potem w prawdziwej walce dzielnie stawić czoła przeciwnikowi, tak niech i młodzieniec uczy się w domu rodzinnym”; tamże 31, SCh 188, 124, BOK 19, 84: „Zamknij mu też usta przed złą mową. Gdy widzisz, że oczernia kogoś, każ mu milczeć i myśleć o własnych błędach”.

${ }^{28}$ Por. tamże 63, SCh 188, 150, BOK 19, 95: „Nie dopuśćmy do wydelikacenia ciała przez szaty ani do poufałego zetknięcia się z ciałem innego człowieka. Hartujmy ciało, by wychować żołnierza

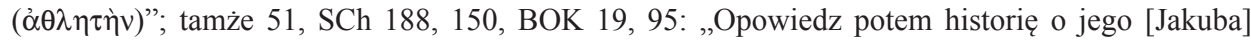
swataniu i powrocie. I to dostarczy wiele pożytecznych zastosowań. Patrz, jak dziecko uczy się tu pokładać nadzieję w Bogu, nie gardzić nikim, przystosowywać się do prostego sposobu życia, znosić dzielnie niewygody, i innych rzeczy".

${ }^{29}$ Por. tamże 39, SCh 188, 130, BOK 19, 86: „Niech zatem nie słyszy [dziecko] takich bajek. A gdy się zmęczy nauką, opowiedz mu coś z historii świętej - bo jego umysł chętnie przyjmuje dzieje lat dawnych i zapomina przy tym o dziecinnych zabawkach. Wychowujesz przecież filo-

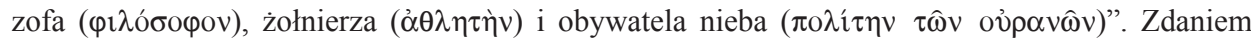
A.M. Malingrey (SCh 188, 131, nota 4) termin „filozof” został zapożyczony przez Chryzostoma od apologetów zwłaszcza Justyna; zob. też De educandis liberis 40-41, SCh 188, 136-138, BOK 19, 86: „Jeśli już więcej razy słyszał, zapytaj je: «Opowiedz mi tę historię» [...]. Dobrze będzie, jeśli też dołączysz praktyczne zastosowanie: «Widzisz, jak złą rzeczą jest zazdrość brata! Widzisz, jak złą rzecza mniemać, iż można ukryć się przed Bogiem. Bóg wszystko widzi, również to, co się dzieje w skrytości». Jeśli tę prawdę wpoisz dziecku, nie będzie już ono potrzebowało wychowawcy. Bojaźń Boża pozostanie w jego duszy i będzie mocniejsza, niż bojaźń przed wychowawcą [...]. Nie poprzestań na tym, lecz zaprowadź dziecko do kościoła, zwłaszcza po przeczytaniu tego opowiadania. Zobaczysz, jak będzie się cieszyć i radować, iż już zna to opowiadanie, którego inni muszą się dopiero uczyć. Z czytającym razem mówi, a nawet go uprzedza, potwierdza prawdziwość czytania i radośnie jest nastawione. Tak treść utrwala się w pamięci”; tamże 52, SCh 188, 150-152, BOK 19, 92: „Gdy dziecko podrośnie, opowiedz mu jeszcze inne historie. Napełnią go one zbawienną bojaźnią. Jak długo zdolność poznawcza jest delikatna, nie należy go obarczać niczym ciężkim, by go zbyt nie przytoczyć. Gdy jednak ma już lat piętnaście czy więcej, niech usłyszy o piekle, a w dziesiątym czy ósmym roku życia lub nawet wcześniej niech się dowie o potopie, zniszczeniu Sodomy i wypadkach w Egipcie, o sądzie w całym opisie. Wzrastając niech też pozna historię Nowego Przymierza, czas łaski, naukę o piekle. Opowiadaniami z własnego doświadczenia zainteresuj uwagę dziecka". 

d) wdrażanie do życia w bojaźni Bożejo,
e) wizyty u świętych mężów ${ }^{31}$,
f) naukę modlitwy i praktykę postu ${ }^{32}$,
g) nadawanie chrześcijańskich imion ${ }^{33}$.

${ }^{30}$ Por. tamże 67, SCh 188, 166, BOK 19, 96: „Tak i Bóg wychowuje ludzi - groźbą kary piekła i obietnicą nagrody nieba. Podobnie i my winniśmy się odnosić do dzieci”; tamże 40, SCh 188, 138, BOK 19, 88: „Jeśli już więcej razy słyszał, zapytaj je: «Opowiedz mi tę historię» [Kain i Abel] [...]. Dobrze będzie, jeśli też dołączysz praktyczne zastosowanie: «Widzisz, jak złą rzeczą jest zazdrość brata! Widzisz, jak złą rzeczą mniemać, iż można ukryć się przed Bogiem. Bóg wszystko widzi, również to, co się dzieje w skrytości». Jeśli tę prawdę wpoisz dziecku, nie będzie już ono potrzebowało wychowawcy. Bojaźń Boża pozostanie w jego duszy i będzie mocniejsza, niż bojaźń przed wychowawcą”; tamże 52, SCh 188, 150-152, BOK 19, 92: „Gdy dziecko podrośnie, opowiedz mu jeszcze inne historie. Napełnią go one zbawienną bojaźnią. Jak długo zdolność poznawcza jest delikatna, nie należy go obarczać niczym ciężkim, by go zbyt nie przytoczyć. Gdy jednak ma już lat piętnaście czy więcej, niech usłyszy o piekle, a w dziesiątym czy ósmym roku życia lub nawet wcześniej niech się dowie o potopie, zniszczeniu Sodomy i wypadkach w Egipcie, o sądzie w całym opisie. Wzrastając niech też pozna historię Nowego Przymierza, czas łaski, naukę o piekle. Opowiadaniami z własnego doświadczenia zainteresuj uwagę dziecka”; tamże 19, SCh 188, 102 104, BOK 19, 80-81: „Mając wiele grzechów na sumieniu, przez jedno możesz je zmazać: wychowaj

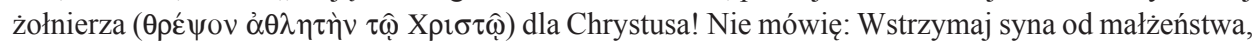
poślij go na pustynię i każ mu zostać mnichem. Prawda - chciałbym, aby wszyscy żyli jak mnisi.

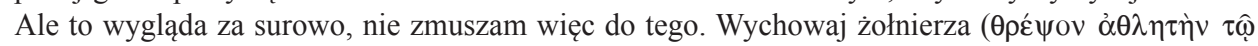

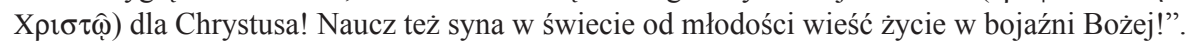

${ }^{31}$ Por. tamże 78, SCh 188, 180, BOK 19, 99: „Zaprowadźmy go do świętych mężów”. A.M. Malingrey uważa (SCh 188, 180, nota 4).

32 Por. tamże 79-80, SCh 188, 182-184, BOK 19, 99: „Niech chłopiec przyzwyczai się do postu przynajmniej dwa dni w tygodniu - we środę i piątek. Niech też uczęszcza do kościoła [...]. Niech nauczy się chłopiec pobożnej i szczerej modlitwy. Nie mów, że dziecko jest do nie niezdolne. Właśnie chłopiec ma bystry umysł i serce skłonne do modlitwy. Mamy wiele na to przykładów, np. Daniela i Józefa.... Czyż Jeremiasz i Daniel nie mieli po dwanaście lat...? Czyż i Salomon nie liczył dwunastu lat...? Czyż Samuel nie uczył jako chłopiec swego nauczyciela? [...]. Niech zatem chłopiec nauczy się serdecznej modlitwy i w miarę możności czuwania. Na całym jego zachowaniu niech będzie wyciśnięte piętno świętości”; tamże 28, SCh 188, 114-118, BOK 19, 83-84: „Złote bowiem jest miasto, które budujemy, i nie ludzie, lecz sam Król wszechrzeczy ma w nim mieszkać [...]. Sporządźmy więc drzwi i zamek ze złota - to jest święte słowo Boże [...]. Uczmy dzieci, by je ciągle miały na ustach, również w drodze, nie bezmyślnie, lecz z zastanowieniem się, nie tylko czasem, lecz zawsze [...]. Nauczmy dzieci wypowiadać tylko przystojne i pobożne słowa [...]. Niech otwiera dziecko usta dla dziękczynienia i świętych hymnów, niech mówi zawsze o Bogu i o filozofii wzniosłego życia”; tamże 34, SCh 188, 126, BOK 19, 85: „Naucz więc syna chwalić Pana w psalmach, aby nie miał czasu i ochoty do brzydkich piosenek i złych rozmów”.

${ }^{33}$ Por. tamże 47-48, SCh 188, 146, BOK 19, 90-91: „Nie należy im nadawać imion ojca, matki, dziadka i pradziadka, lecz świętych - męczenników, biskupów i apostołów. Niech takie imię pobudzi ich do gorliwości [...]. Przy wyborze imienia unikajmy zwyczajów pogańskich. Jest rzeczą brzydką i śmieszną, iż w chrześcijańskim domu panują zwyczaje pogańskie”; tamże 50, SCh 188, 148, BOK 19, 91: „Nie uważaj tego za rzecz małą, bo już imiona świętych przynoszą błogosławieństwo”. 
4. Wychowanie jako ksztaltowanie Bożego obrazu. Chryzostom podkreśla wagę problemu wychowania i ciężar odpowiedzialności, jaki spoczywa na chrześcijańskim ojcu.

„Jak malarze nad obrazem i rzeźbiarze nad posągiem pracują z wielkim wysiłkiem, tak i wy - ojcze i matko - musicie włożyć wiele starania w wychowanie swoich dzieci, tych podziwu godnych obrazów [...]. Tak i wy rodzice, jak wykonawcy pięknych posągów, musicie wkładać wszystek trud, aby swe dzieci wychować na piękne obrazy Boga. Usuwajcie to, co niepotrzebne, uzupełniajcie braki; z dnia na dzień baczcie na skłonności swych dzieci, na dobre, by je rozwijać, na złe, by je wykorzeniać" ${ }^{34}$.

Religijne wychowanie wymaga od ojca wiele wysiłku i nieustannej obserwacji dziecka, chodzi bowiem o kształtowanie w nim Bożego obrazu. Skuteczność pedagogicznych zabiegów zależy od stałości i konsekwencji w procesie wdrażania ideałów porządku i dobra ( $\left(\dot{v} \theta \mu \mu_{i} \zeta \varepsilon \imath v\right)^{35}$. Jan ilustruje swoją myśl przykładami malarza i rzeźbiarza. Ojciec w trudzie wychowywania tak potomstwa, jak i żony ${ }^{36}$, przypomina nie tylko artystę, ale nade wszystko samego Stwórcę ${ }^{37}$. Pedagogiczny postulat naśladowania dobra na przykładzie czy to postaci biblijnych, czy uprawiających ascezę eremitów, czy też dbającego o swój duchowy rozwój pater familias, znajduje swoje źródło w religijnym imperatywie odzwierciedlania ideału Boga. Warto podkreślić realizm Chryzostoma w ocenie postawy i zachowania dziecka: Kaznodzieja wyraźnie wskazuje na jego dobre i złe skłonności. Wyraźnie również rozciąga obowiązek wychowywania na matkę, z zastrzeżeniem pierwszoplanowej roli ojca ${ }^{38}$; pozostali domownicy mogą współpracować w tym trudnym dziele, o ile ojciec pozytywnie oceni ich pedagogiczne zdolności is ${ }^{39}$.

Konkludując, można powiedzieć, że program wychowania w ujęciu Jana Chryzostoma jest w pełnym tego słowa znaczeniu programem religijnym: klasyczna idea naśladowania i różnorodne metody pedagogiczne włączone zostały w proces wdrażania dziecka do porządku i dobra oraz kształtowania w nim obrazu Stwórcy. Pater familias jest odpowiedzialny za wychowanie swojego potomstwa. W postulatach Złototustego widać wyraźny wpływ ukochanych przez niego ideałów monastycznych ascezy, modlitwy, znajomości Pisma Świętego. Łatwiej również zrozumieć koncepcję pedagogiczną Jana,

${ }^{34}$ Tamże 22, SCh 188, 106-108, BOK 19, 81.

${ }^{35}$ Por. tamże 24-31.

${ }^{36}$ Por. In Matthaeum hom. 30, 5-6, PG 57, 368-370, ŹMT 18, 361-362.

${ }^{37}$ Por. De educandis liberis 67, SCh 188, 166, BOK 19, 96: „Tak i Bóg wychowuje ludzi groźbą kary piekła i obietnicą nagrody nieba".

${ }^{38}$ Por. In Matthaeum hom. 11, 8, PG 57, 201-202, ŹMT 18, 145.

${ }^{39}$ Por. De educandis liberis 38, SCh 188, 130, BOK 19, 86: „Tylko wypróbowani winni pomagać w kształtowaniu Bożego obrazu [...]. Tylko odpowiedni domownicy mogą w tym pomagać”. 
gdy nie pomija się znaczenia prorockiego napominania w jego kaznodziejstwie i pasterzowaniu.

\section{ÉDUCATION RELIGIEUSE \\ DANS LES TRAITÉS DE JEAN CHRYSOSTOME}

\section{(Résumé)}

L'analyse de cet article se porte sur l'idée de l'éducation religieuse des enfants dans les traités de Jean Chrysostome. „Bouche d'or” s'attache à montrer que pour assure une éducation soignée les parents (en particulier le père) sont obligés de développer et d'approfondir le sens et la motivation de la vie religieuse chez leurs enfants. Dans sa argumentation il donne une immense série d'exemples scripturaires et monastiques qui Pater familias doit utiliser pour former l'image du Dieu le Createur dans l'éducation religieuse. La conception pedagogique de Chrysostome est en conséquence soumit à son devoir du prédicateur prophétique. 